United States Dispensatory spoke of them as occasionally employed in cases of chronic diarrhœa. The last (20th, 1918) edition contains the somewhat contradictory statement that they "are no longer prescribed internally. Aromatic syrup of galls is sometimes prescribed." This syrup is a form in which they were employed in the treatment of diarrhœa.

Officinal galls are derived almost exclusively from Quercus infectoria, and this is recognized as their source in the United States Pharmacopœia. They are produced by Cynips galletinctorice Olivier, and are of the well-known hard, spherical type, about ten to twenty millimeters in diameter. They are often known in commerce as the Aleppo galls, since they formerly were largely produced in the vicinity of the Syrian city of that name.

The most significant feature of the use of galls by the Indians for the same disease as that for which the officinal preparations were more of ten used, is that the Indians use a type of gall differing radically from that above described. Doubtless both owe their efficacy to the presence of tannin but it is clear that the Indian usage could not be a modern one, derived from that by the whites.

\title{
Scientific Notes
}

Hessian Fly: Supplementing previous outdoor experiments, to determine whether or not certain strains of wheat are actually less severely attacked by the Hessian fly than others, the Department of Entomology of the Missouri Agricultural Experiment Station is carrying through an interesting series of greenhouse experiments. Some difficulty has been experienced in making growing conditions absolutely uniform, where a large series of varieties are tested and the conditions under glass are naturally not exactly the same as in the field. Standard Missouri varieties as well as others previously reported as having resistant qualities are being used in the experiments. The pest seems to breed and develop norma'ly indoors on all strains tested, but in the first test just completed, some varieties are decidedly less severely attacked than others. Chemical tests and observations on different structural variations of the indoor plants are also being made the same as in case of the field experiments.

Leonard Haseman.

European Corn Borer In Connecticut: What appears to be a small infestation of the European Corn Borer, Pyrausta nubilalis Hubner, was found in Milford, Conn., March 12, by assistant entomologists from the Agricultural Experiment Station. The infestation lies just north of the village, and at this writing its limits have not been definitely ascertained. Prompt measures will be taken to suppress the pest.

W. E. Britron. 
A Correction: In the Journal of Econome Entomology, Vol. 11, No. 5, p. 431, I made the statement that I had found the Cherry-Leaf-Beetle, Galerucella cavicollis LeC., feeding on several species of azales. This azalea feeding beetle, I now find, on more carefully comparing the specimens, is Galerucella rufosanguinea Say. To my good friend, Dr. E. A. Schwarz, I am indebted for calling my attention to the matter.

Berkeley, Cal., March 3, 1919.

Edwin C. VAN Dyke.

A New Root Maggot Treatment. The soils and climatic conditions of the Pacific Coast are such that most cruciferous crops thrive exceptionally well. Cabbage, cauliflower, turnips, radishes and the like are grown in most every garden and are standard market garden crops; thousand-headed kale is grown by almost every dairyman and poultryman; and the cabbage seed-growing industry of the United States is centered largely in Skagit County of the State of Washington. These crops are therefore very important in the agriculture of western Washington. All of these crops are infested more or less each year by the cabbage root maggot (Phorbia brassicae Bouche). The damage done by this pest makes it one of the most important insect pests which we have to combat.

Each senson for many years past experiments looking toward the control of this pest have been carried on at the Western Washington Experiment Station. New treatments tried from year to year have so added to the "found wanting" list that it makes quite an impressive array of blighted hopes. Of the many treatments that have been tried, the tarred felt collar for transplanted crops such as cabbage, kale and cauliflower has been the most effective prior to this season.

The use of powdered borax to kill house-fly maggots in manure as recommended by the United States Department of Agriculture and the successful use of "green tar oil" in English army camps to prevent manure heaps from becoming a breeding place for house-flies suggested to the writer their use for root-maggot control. Accordingly, this past season these two materials were tried along with the usual number of new "remedies."

The recommended borax treatment to kill house-fly maggots in manure is 1 pound of powdered borax to 16 cubic feet of manure. Based on this recommendation $\frac{7}{2}$ pint of a solution in which 1 ounce of powdered borax is dissolved in 10 gallons of water should effectively treat 10 cubic inches of soil. This was assumed to be about the proper treatment for one plant. Solutions of 1 ounce of powdered borax to $2 \frac{1}{2}$ gallons, 5 gallons, 10 gallons and 15 gallons of water were used at the rate of $\frac{1}{3}$ pint to the plant. The stronge concentrations had a slightly injurious effect on the kale plants, thousand-headed kale being used in these experiments. Some few plants were killed and others were noticeably stunted. These treatments showed practically the same percentage of loss as the checks, so are apparently of no value in the control of root maggot.

"Green tar oil" used at the rate of 1 part to 40 parts of soil, applied 1 inch thick on manure heaps, has been reported (W. H. Saunders in the 1916 Proceedings of the London Zoblogical Society) to effectively protect them from becoming a breeding place for house-flies. This oil is a heavy coal tar distillation product known in this country as anthracite or anthracene oil. It is insoluble in water and non-volatile. It was obtained from The Barret Company, New York, and The Republic Creosoting Company, Seattle. The latter company reports that anthracene oil will retail at approximately $\$ 1$ a gallon.

In our experiment with anthracene oil, soil from the field in which the transplanting was to be made was used as a carrier rather than anything else, because in that way 
nothing other than the oil was introduced and because the mixture was easily made, simple and inexpensive. The anthracene-oil-treated soil was scattered around the base of the plant to form a protecting collar, 1 gallon of the mixture being used to about 200 plants. The rates used were 1 part of the oil to 20,40 and 80 parts of soil by measure. It was hoped to establish the upper and lower limits of concentration that were effective and non-injurious. The 1 to 20 mixture proved injurious to the plants, as a number died as a result of the treatment. The results indicate that the 1 to 80 mixture may be stronger than necessary, as this treatment proved most effective. Distillate was used in one test to thin the oil to facilitate mixing. The treatments were applied as soon as the kale was transplanted. The results secured with these treatments follow:

\section{Kale Transplanted July 6-10}

Treatment

Untreated

Anthracene, 1-20

Anthracene, 1-40

Untreated

Anthracene, 1-80

Anthracene, $1-40$

(Oil diluted with distillate)

Untreated

3 Untreated

4 Anthracene Treatments

Tarred Falt Collars

Number of Final Count of Plants Treated Missing Plants

185

70

80

35

125

\section{1}

185

305

336

184
86

$14^{1}$

10

17

13

12

59

162

49

27
Per Cent of Loss

46.5

20

12.5

48.6

10.4

19.8

31.9

40

14.6

14.7

As only a small amount of anthracene oil is necessary in the mixture and soil is a satisfactory carrier, this treatment is cheap, readily prepared and easily applied. If it proves as effective in succeeding seasons as it did in our experimental plots this year it should come into general use

E. B. STOoKey.

\section{MEETING OF PACIFIC SLOPE BRANCH AMERICAN ASSOCIATION OF ECONOMIC ENTOMOLOGISTS}

The annual meeting of the Pacific Slope Branch will be held in connection with the State Fruit Growers' Convention, at the Citrus Experiment Station, Riverside, Cal., May 28 and 29.

This meeting has been set especially to accommodate the visiting Eastern and middle West entomologists, many of whom are to attend this convention. Regular announcements have been sent to all members living west of the Rocky Mountains. Earlier decisions to hold this meeting at Berkeley or Pasadena have been changed in favor of Riverside as stated above.

A cordial welcome is extended to all visiting entomologists. They will find the Citrus Experiment Station and the School of Subtropical Agriculture most interesting and inspiring. The meetings and discussions can not fail to interest entomologists.

\section{H. J. QUAYLE, Chairman.}

E. O. Essig, Secretary.

\footnotetext{
1 Part of loss due to the effect of the treatment.
} 